\title{
Dramaturgies of humour in the performance of protest
}

\author{
Sruti Bala \\ Theatre Studies/University of Amsterdam \\ s.bala@uva.nl
}

\section{Veronika Zangl}

Theatre Studies/University of Amsterdam v.zangl@uva.nl

\begin{abstract}
The article analyses three instances of artistic activism from the $21^{\text {st }}$ century in terms of their dramaturgies of humour. The cases examined are the procession of "the human gorging society" by Viennese collective Rebelodrom in 2013, the 2012 lecture-performance "The Return of Border Brujo" by Chicano performance artist Guillermo Gómez-Peña and the ongoing Tracking Transience project by US-American artist Hasan Elahi. By extending the concept of dramaturgy from theatre theory to the study of protest and activism in the public sphere, and by interpreting the chosen artistic actions as protest, the article seeks to contribute to humour research from a perspective that focuses on its performative dimension, rather than on its functions or effects alone. The term "dramaturgies of humour" refers here to both principles of ordering as well as of unfolding an idea, which inform an act as humorous. In these instances of artistic activism, humour does not simply mark one characteristic or component of protest, but is indeed the embodied, performed means through which the protest is constituted. The article employs a reading of Mikhail Bakhtin's work on the grotesque, and in doing so, adapts the concept originally developed in relation to literary texts to the study of artistic activism. Such a focus on the dramaturgies of humour leads to two notable insights: first, that protest using a ludic aesthetic creates and sustains a highly ambivalent relation between activists and their opponents, specifically through a playful questioning of the logic of protest in terms of opposition. Second, the dramaturgy of humour in protest reveals a strong historicity: each of the examples reference the past in sophisticated ways, and the shifting narratives of memory are integral to humour as a link between memory and imagination.
\end{abstract}

Keywords: dramaturgy of humour, grotesque images, memory. 


\section{The dramaturgy of humour}

Humour research has developed a considerable body of highly differentiated theories on various phenomena, ranging from philosophical and anthropological reflections on humour and laughter to sociological, psychological and linguistic classifications of humorous utterances (Morreall 2009; Hart \& Bos 2008; Billig 2005; EJHR 1 [2], 2013). It is striking that the predominant theories, i.e. incongruity, superiority, and relief theories, reflect on humour in terms of its function and its effects. This corresponds to an understanding of humour from either a producer's perspective (the effects, functions and purposes intended by the producer of humour), or a receiver's perspective (the way humour is interpreted, the responses it generates in its receivers or target audiences). Accordingly, humour serves complex purposes when it comes to cultural, social or political conflicts, ranging from disciplining or discriminatory to subversive and disruptive functions (Bergson 1999; Hart \& Bos 2008; Kuipers 2011). ${ }^{1}$ This ambivalent character of humour provides ample scope for research, however not only in terms of its functions or effects, but also in various other ways. This article analyses three instances of artistic activism from the $21^{\text {st }}$ century in terms of what we term as their dramaturgies of humour. The cases examined are the procession of "the human gorging society" by Viennese artistactivist collective Rebelodrom in 2003, the 2012 lecture-performance "The Return of Border Brujo" by Chicano performance artist Guillermo Gómez-Peña and the ongoing Tracking Transience project by Bangladeshi-American artist Hasan Elahi.

Dramaturgy, in our application of the term, refers to the principles of ordering and of unfolding an idea through various means, such as narrative, embodiment, and the interaction of bodies, objects and spaces (van Kerkhoven 2009; Boenisch 2012; Pewny \& Callens \& Coppens 2014). To analyse the dramaturgies of humour implies examining, on the one side, the principles of ordering and structuring of humorous acts, gestures, moments and events, as well as the principles of their unfolding and enactment. Such an examination is less concerned with the functions it serves for its producers and recipients and more with its processes. By extending the concept of dramaturgy from theatre theory to the study of protest and activism in the public sphere, and by interpreting artistic actions as protest, the article seeks to contribute to humour research from a perspective that focuses on its performative dimensions (Bala and Zangl 2015). In the chosen instances of artistic activism, humour does not simply mark one characteristic or component of protest, but indeed becomes the embodied, performed means through which the protest is constituted. The performative dimension pertains to both the producers as well as the recipients, and adopts a multi-directional perspective on the communication between producers and recipients, whereby receivers do not merely fulfil the task of interpreting or making sense of humour produced elsewhere, but equally participate in its constitution. The article thus argues for attention to the dramaturgies of humour, as a way of supplementing the functional theorisations of humour. We argue that such an analysis leads to two notable insights: first, the highly ambivalent characteristics of artistic-activist humorous acts in a context of conflict; and second, the strong historicity of such acts, both with regard to their invocation of the past as well as in terms of the condensation of history in grotesque images. ${ }^{2}$

The term dramaturgy in this context is thus not a metaphor, but a concept that opens out the study of humour in protest according to the inter-relations and interactions between artistactivists, opponents, their audiences and the acts of protest. In assessing examples of artistic activism, the deployment of humorous strategies reveals that the communication with the opponent, whether a higher authority, the ruling power or a system of oppression, is far from a 
straightforward opposition. This article charts some of the complex and ambivalent ways in which humour transforms how an opponent is conceived and addressed (Boenisch 2010).

Another association between theatre theory and conflict theory stems from the concept of dramaturgy as a multi-layered, relational arrangement of acts (Pewny, Callens \& Coppens 2014; Trencsényi \& Cochrane 2014), be it an act of protest, an artistic act, or both simultaneously. Examining the dramaturgy of humour in protest or other forms of activism implies taking a closer look at the form that humorous acts of artistic protest take and at the mode of presentation chosen. Do they rely on a representative mode, mimicking or ridiculing, exaggerating and putting on stage what they seek to oppose? What is expressed through verbal or textual means and what remains a momentary, ephemeral, though memorable embodied gesture? This understanding of dramaturgy allows for a careful examination of the 'how' in addition to the 'what' of humorous protest. How is the serious core of the activist aims balanced with the lightness that usually accompanies humour? What plot line or narrative approach is employed? How, if at all, is the space provided for heterogeneous responses?

The article examines three case studies in terms of their dramaturgies of humour, taking into consideration both senses of dramaturgy as outlined above, namely the principles of ordering or structuring and the principles of unfolding or opening out. Despite differences concerning time, locality, cultural background, cultural positioning, and types of conflict, the three examples share certain crucial similarities. They all took place in the span of the last decade and have their origins at the beginning of the $21^{\text {st }}$ century. Rebelodrom's street procession took place prior to the Austrian national elections in 2013, Hasan Elahi's Tracking Transience project was initiated in 2002 and while Gómez-Peña's lecture-performance in Amsterdam was held in 2012, the earliest versions were presented shortly after the event that has come to be called 9/11 in 2001 . All three projects take up the issue of immigration, illegality and the restrictive policies of national borders, though each responds to specific regional or national circumstances. All three work with an aesthetic comprising of elements such as exaggeration, heterogeneity, grotesqueness and disproportionality. Stereotypes and repetitions are used both as a manner of attacking others, as well as a means of humorously addressing the self. Further, all three cases consciously use historical references as a constituent element of their humour. Although they address a contemporary and current political issue, the humour in their artistic activism is closely interwoven with references to the past, playing with memory and shifting 'grand narratives'.

Given both this remarkable conjunction with memory of their humour as well as the ambivalent qualities of its expression, it is not surprising that the work of Mikhail Bakhtin appears as a source of inspiration to this study (and indeed also for other essays in this volume). Bakhtin's unorthodox approach to folk culture underscored what he termed its "heteroglossia", its multiplicity of styles and its "dialogicity" (Bakhtin 1981). Mikhail Bakhtin carefully elaborated on the basically ambivalent character of humour in his canonical study on carnival and the grotesque image (Bakhtin 1984). Even though he sourced his observations primarily from literary texts, his conceptions of the carnival and the grotesque are not simply restricted to the realm of language and narration, but are applicable to physical, often collective public acts and events. Bakhtin's analysis of humour's multifaceted modes of address is pertinent to our understanding of the corporeal dimension of protest in contemporary artistic activism. In his canonical study on Rabelais, the fundamentally ambivalent images of the grotesque body are read as marking a utopian moment (Bakhtin 1984: 9-10). However, Bakhtin constructs a kind of ideal concept of the grotesque and therefore interprets grotesque images from the Romantic period and from the beginning of the $20^{\text {th }}$ century as degenerated versions and as fractured 
depictions of the wholeness that he believed medieval grotesque images once expressed (Bakhtin 1984: 52-53). In contrast to such a universal conception, our study of artistic activism departs from the premise that the grotesque image needs to be historicised. To historicise means to analyse how the historical, cultural and socio-political contexts find their respective expressions in contemporary grotesque images and articulations.

\section{Ridiculing cultural memory: REBELODROM/maiz}

During the run-up to the Austrian elections in 2013, the notorious right-wing populist party FPÖ (Austrian Freedom Party) under the leadership of Heinz-Christian Strache was predicted to win the election. A central issue of the FPÖ election campaign were xenophobic slogans like "Asylbetrüger haben zu gehen [Asylum impostors have to leave]" or "Liebe deine Nächsten. Für mich sind das unsere Österreicher [You shall love your neighbour. For me these are our Austrians]". Rebelodrom, a platform of civil society initiatives such as Romano Svato, maiz, traschq, Marea Alta initiated by artist-activists Gin Müller took part at the so-called WIENWOCHE (Viennese Week) ${ }^{3}$ with a series of humorous interventions in public space.

One of the artist-activist-groups, maiz, an autonomous centre by and for immigrants, performed a cannibalistic procession entitled Eating Europe! or menschenfressende Gesellschaft [human gorging/anthropophagic society]. By adopting the format of a procession for the public intervention, Rebelodrom/maiz provoked and quoted a multi-layered memory-landscape: to begin with a religious tradition of the predominantly Catholic country, the formation of demonstrations as well as street actions of artistic predecessors like the Wiener Gruppe. Furthermore humorous references were drawn to Oswald Andrade's manifesto of anthropophagy from the Brazilian avant-garde movement in the early twentieth century. The street intervention took place at the heart of culturally charged sites like the Karlskirche, Künstlerhaus and Musikverein in Vienna. The anthropophagic procession contrasted the thoroughly preserved historical sites of the city with a spectacle of queer body images, counteracting religious, national and gender identities. The carnivalesque group included a number of rickshaws with canvas topping in Austria's national colours red-white-red, carrying a Holy Mary in a pink glitter dress, fishnets and a kitschy crown of golden lamps on a white veil, playing lasciviously with a lash; or an aristocratic looking couple, the woman with a sort of Louis XIV-wig, the man carrying a parrot; a limping woman in dirndl, dragging a colossal penis of silver foil behind her; a man in a pink dirndl and high heels, black dressed anarchistic rebels with bivak masks; a woman dressed as cardinal in pink dress and one in a white dress contacting a voodoo-like cannibalistic ritual in the front of the Karlskirche. The embodiment of these grotesque images visualizes the ingredients of a seemingly homogeneous identity politics based on Catholicism, (rural) tradition and high culture by exposing its inherent contradictions. Rebelodrom/maiz stresses the corporeal aspect of the grotesque, through a joyous celebration of queer body images, colonial and postcolonial stereotypes and exaggerated embodiments of official representatives of church and politics. Their artistic activism blurs the dramaturgical concept of antagonist/protagonist and pushes it towards a heterogeneous dramaturgy of humour by incorporating and simultaneously exposing the opponent in order to de-form and newly re-form ${ }^{4}$ unified visions of identity.

However, the recital of a carnivalesque litany "We have come to gorge Austria, we have come to gorge Europe, $[\ldots]$ we have come to gorge FPÖ" by no means demonstrated a reference to Bakhtin's concept of universalism and regeneration. The refrain "but we do not digest it; we get diarrhoea" rather performed a satirical critique of Bakhtin's dialectics of grotesque images. 
Bakhtin depicts the dark and tragic romantic concept of the grotesque as a disintegration of "the positive pole of grotesque realism," (Bakhtin 1984: 53) namely the principle of regeneration, its universal spirit and utopian perspective. Yet, the rejection to digest cannot be reduced to a "fear of the world" or a world "turned into something alien" (Bakhtin 1984: 39, 42). The anthropophagic procession is rather a manifestation against mechanisms of inclusion and exclusion, against dialectics of destruction and regeneration, characteristic for unifying concepts of identity politics. By applying a dramaturgy of heterogeneity or rather a dramaturgy of dissonant constellations, the utopian moment is constructed as aesthetic attitude reaching unmediated reality (Müller 2008). The anthropophagous procession applied a strategy of grotesque hyper-realism in order to oppose those local and global economic and political structures that reinforce inequality. Ironically, the hyper-real strategy of Rebelodrom/maiz and, with its distinctive aesthetics of exaggeration and visceral corporeality, in fact reflected the grotesque features of the emerging globalized reality.

\section{Refracting the surveilling gaze of the public}

The second case study deals with an instance of an individual act of protest that eventually became an artwork. Hasan Elahi, a Bangladeshi-American media artist and scholar based in Washington DC, was detained at an US Airport in 2002 on suspicions of being involved in "terrorist" activities. The detention had severe consequences, for he was informed that his whereabouts would be monitored for one year. Elahi responded to this by inverting the surveillance of the state. He first started sending, or spamming if you like, the authorities with mails, photographs and text messages about every bus or flight he took, every restaurant he ate in, every toilet or hotel room he visited, every waiting room he spent time in. Gradually this sousveillance, state surveillance reversed by the citizen as self-surveillance, unfolded into an ongoing art project titled Tracking Transience (Elahi 2014). In a given asymmetrical conflict situation, where the overwhelming mechanisms of state power intrude into the life of a citizen marked as ethnic minority or immigrant, it is the self-ironic gesture that serves as a lens to investigate not the innocence of the one being watched but the monstrosity of the system of surveillance.

The dramaturgy of Elahi's humour can be described as an assemblage of arbitrary and accurate images. The website and self-designed tracking software is consciously user-unfriendly and cluttered, thus ironically creating a kind of privacy precisely through extreme visibility (Elahi 2011: 6). Through the overloaded archiving of transient images, Elahi creates a special kind of open response, in which he inscribes himself as an artist into the times he is commenting on, questioning the certainty and safety that surveillance purportedly provides, and making sure, in the Derridean sense of the archive, that objects are consigned to the archive to be forgotten, to be unfindable (Derrida 1996: 3). Thus although the project seems to track a certain transience, it is an attempt by means of exaggeration and paradox to protect this transience by making it untraceable. At the same time, the massive collection of seemingly precise images showcased on the website of Tracking Transience points to the other aspect of the Derridean reading of the archive, derived from one of the Greek root meanings of the term arkhé, "there where men and gods command, there where authority, social order are exercised, in this place from which order is given" (Derrida 1996: 1), a somewhat tongue-in-cheek reference to the US National Surveillance Agency and its omnipresence in commanding geopolitical order and seeking to compile virtually all existing information in the world. Consider, for example, some of Elahi's 
images of public toilets he has visited, or plates of food he has probably ordered in a restaurant, marked with information such as the time of day, a precise longitudinal-latitudinal location or a figure that could be a bank balance or a random calculation from a spreadsheet. The images offer a combination of apparent accuracy as well as arbitrariness. They tell you nothing by telling you a lot. They offer information, which appears, at first glance, to be a secret view into a private life, such as a view of a used bed in a hotel room, or a shopping cart with selected items, and yet these images are highly impersonal. Not a single face or body is visible; we see a bed after someone has slept in it, but we don't know who used it, or where it is located, and what it tells us about the person who slept in it. The endless reiteration of dozens, if not hundreds of images of plates of food, highways or of building corridors further adds to a dramaturgy that adopts a specific type of public viewpoint, one that is paradoxically both precise as well as random and irrelevant, collecting not knowledge but what has been referred to as a "dataesthetic" (Holmes 2009: 96).

The images in Tracking Transience, or at least those made during the period of Elahi being placed under state surveillance, were not only exhibited in art gallery and online settings, but also actually sent by Elahi to the FBI. From the perspective of analysing the project as a form of activism, it thus employs an equally heterogeneous, unorganised dramaturgy. There is as much evidence to show that the project is genuinely helping the authorities by doing the surveillance for them, as there is evidence to show that the project is ironic. As Grindon argues in a study on irony in cultural activism, Elahi's work does not seek to "inspire or awaken a supposedly passive subject, but engages in culture while understanding it as a directly political field. That is, it seeks to take a direct, active, organizational role in relation to the already present, already active desires of subjects" (Grindon 2010: 21-34). Rather than making a statement speaking out against surveillance or writing a protest letter, the activist gesture is one of taking on the surveillance directly by being involved in it. Such methods have an artistic legacy that can be linked to vastly different traditions, from the storytelling tradition of the 1001 Nights, where the narration of a vast number of stories served as a means of survival, or to the Absurdist gesture of leading cacophonies into silence, or the Situationist practice of the dérive. They have in common a use of hyperbole as well as a hyper-literal interpretation of a task or question (BAVO 2007).

The safety and privilege provided by positing the self-surveillance information as art may well not be granted to anyone under every circumstance, as it providently turned out to be for Elahi. It is not difficult to think of countless examples of people whose visibility became dangerous for them, and led to even more aggressive surveillance. That Elahi could get away with it, without being penalised, makes Tracking Transience so humorous. Even less than a decade later, when the extent of global surveillance is becoming evident and the surveillance far from transient, the humour of Elahi's Tracking Transience almost borders on the nostalgic. His example thus highlights questions of memory in relation to humour, wherein the conception of a conflict fundamentally affects and shapes the type of humour that emerges. In contrast to the data revealed by whistleblowers on the extent of surveillance machinery worldwide, Elahi's project is humorous for different reasons today than it initially was. Tracking Transience appears today not as a magnified, exaggerated version of state surveillance, but as a mere miniscule sample of its possibilities. 


\section{Testing! Testing! Hola? Fortaleze Europa?}

In October 2012 the performance artist and director of the performance troupe La Pocha Nostra Guillermo Gómez-Peña gave a lecture performance at the University of Amsterdam entitled "The Return of Border Brujo". In this lecture-performance, he reflects on the post-9/11 era, and on the current "border wars", between the USA and Mexico, but also in Europe and elsewhere, from his perspective as a Chicano artist. In a way, Gómez-Peña fuses the humorous strategies of Rebelodrom and Elahi by simultaneously poeticizing as well as embodying grotesque images. In his lecture he triggers a multi-layered performative space by applying dramaturgies of duration and fragmentation, by both citing hybrid literary genres and academic theories, and forcing them into challenging multilingual constellations. At the same time, he enacts, embodies and juxtaposes the colonial and postcolonial gaze and inscription of "Fortress Europe" based on a multitude of dichotomies, such as male/female, young/old, self/other, West/East, Global North/South.

The "return" in the lecture-performance "Return of Border Brujo" references Gómez-Peña's classic solo performance "Border Brujo", originally performed in the 1980s and later filmed by Isaac Artenstein. In the early version of the performance, the artist poetically retells how he is accused of "kicking a border patrol officer in the balls for the sake of experimentation ... I mean, for the sake of (s)experimentation", holding his cigar as a placeholder for the gesture of the raised middle finger (Gomez-Peña 1989). The current re-performance of the piece emphasises how not much has changed in some levels in the political scenario, as far as the criminalization of immigrants and border crossers is concerned. On the other hand, the lecture-performance reworks and revises the "border wars" of then to the present situation, he patches together the border problems of the USA with the paranoia in the Dutch public sphere around allochtony and autochtony. He asks God to bless all the rogue states of the world, asking the audience to name them one by one, and after marking this blessing by gulping down a large quantity of local Jenever liquor, he sprays out a mouthful onto the front row. He ironically vents his frustration at "not knowing what radical performance art can do in a time when the images of Abu Ghraib themselves resemble radical performance". He asks, "What else is there to transgress? ... should I masturbate in the name of democracy and freedom ... on YouTube?" The dramaturgy of humour in his activist art does not address an opponent far away or high above, but is addressed to the very same audience of university teachers and students he both depends on, to listen to him, as well as whom he calls into question. He rhetorically asks a question to himself: "What to do if you are too strange to get a chic job in academia?", thus pointing to the institutionalisation of radicalism which he is both reluctant and wishing to be a part of. He criticises the so-called "designer identities" of students, who wear a t-shirt saying 'Art is Resistance' and believe the job is thereby done. The dramaturgy of humour in Gómez-Peña's lecture-performance thus invokes a variety of domains of taste from popular culture, often classified as kitsch, excess and camp. Similar to Bakhtin's reading of Rabelais, Gómez-Peña's humour twists the framework of bourgeois culture and aesthetic norms, rather than operating within it (Bakhtin 1984: 4-5). This makes its humour ambivalent, shifting between the almost affirmative and the not quite dismissive.

Multilingualism is another strong means of introducing historical layers onto grotesque body images. For Gómez-Peña a contaminated, messy multilingualism is very much part of the "poetic act". Combining Spanish, English and Portuguese, he addresses academics in their own 
environment about their own privileges: "“Academia,' this word makes me so...anxious! Aca-de mí ahhh, no...Aca-de-túya."5

Gómez-Peña cites lyrics and poetic rhythms and metres in his lecture-performance and reritualizes language. He incorporates and enriches English with a number of other languages, including some kitsch versions of non-existent indigenous Mexican languages, and playfully combines and contrasts languages to create new constellations of meaning. Like Rebelodrom/maiz his multilingualism can be depicted as an act of cannibalism denying digestion. As he does the mic check with the conventional call "Testing, testing", he adds, "hola, fortaleze Europa!" [Hello Fortress Europe], thus bridging in one small phrase the call of the artist to his audience on the one side, and on the other side, the call of the invisible migrants who seek to cross and enter Europe across its hostile borders. As he continues breathing into the mic, he pushes it entirely into his mouth; what begins as a tender kiss turns into a choking presence, that which allows him to be heard is also that which does not allow him to speak any longer, and this is shown in an anthropophagic gesture of (almost) swallowing the mic, the symbolic connection to the audience. It would be impossible to capture this humour without paying attention to its sensuous, corporeal elements, i.e. to the way objects, the materiality of voice, and physical appearance are dramaturgically played around with, i.e. structured and ordered, while at the same time, opening out possibilities of meaning making, troubling fixed interpretations in terms of function or symbolism. The lecture-performance employs a means of grotesquely approaching the critical message, i.e. a rejection of racism, nationalism and cultural puritanism, through the means of a messy pastiche of idioms, languages, artefacts and bodily expressions.

Unlike Elahi's highly impersonal images of sousveillance, Gómez-Peña's lectureperformance adopts a very personal, confessional note in order to address the responsibility of the public gaze. He speaks of his own personal wounds, he shares his drink with the audience by passing the bottle of liquor around, he incorporates interventions from the audience into his own lyrical speech "God bless ... the Vatican, por qué no?" Such activist art does not just oppose dichotomies as a foundation of identity politics, but creates fractured images and moments of the grotesque, going beyond dichotomies and encountering and embodying the other through a constellation of atomized images. As Sheftel has argued, this humour "offers an alternative mnemonic paradigm", a different mode of presenting and historically placing a critique (Sheftel 2012: 147) and simultaneously offering a self-aware social commentary (158).

\section{Heterogeneous dramaturgies of humour}

Our proposal of analysing such acts of artistic activism or protest through what we term as the dramaturgies of humour offers a supplement to existing theorisations of humour, which focus on their functions and mechanisms. Departing from Bakhtin's insistence on the ambivalent character of humour, we argue that paying attention to the dramaturgies offers the opportunity to analyse the principles of how humorous acts of artistic activism or protest are structured or performed, as well as the principles by which they generate multiple, heterogeneous interpretations. Such a focus on the dramaturgies of humour leads to two notable insights: first, that protest using a ludic aesthetic creates and sustains a highly ambivalent relation between activists and their opponents, specifically through a playful questioning of the logic of protest in terms of opposition. This is one of the main differences from conventional forms of activism, where an opponent is clearly identifiable in most cases. Second, the dramaturgy of humour in protest reveals a strong historicity: each of the examples discussed in this article reference the 
past in sophisticated ways, and the shifting narratives of memory are integral to humour as a link between memory and imagination. The grotesque images and gestures presented in the examples all insert themselves into a legacy of other related historical moments and associations. The evocation of these layers of memory and historical references creates a certain dramaturgy, a convergence of form and content, characterised by a highly ambivalent humour.

Walter Benjamin states in one of his "findings" in The Arcades Project, "It's not that what is past casts its light on what is present, or what is present its light on what is past; rather, image is that wherein what has been comes together in a flash with the now to form a constellation" (Benjamin 1999: 462). Dramaturgies of humour and grotesque images perform and enact such sudden "constellations", they offer principles of ordering as well as unfolding an idea, which informs an act of protest as humorous. However, the examined artist-activist cases not only elucidate the dialectical relation of what-has-been to the now, but also atomize the dialectical images by applying heterogeneous dramaturgies. Precisely these fractured "constellations" contain a non-identical utopian moment and allow spaces for aesthetically rearranging the sociopolitical sphere. Still, the ambivalence of humour as potentially transgressive on the one side, as well as upholding the status quo on the other, make it difficult to draw out general assumptions (Sørensen 2008: 170). It cannot be broadly claimed that humorous approaches are fundamentally different from more conventional formats of activism. However, humorous approaches time and again perform confronting and provocative constellations that do not aim for unifying concepts but open out multiple paths of interpretation and response.

\section{Notes}

${ }^{1}$ Humour can trigger social conflict on a local and global scale as the Danish cartoon crisis demonstrates (Kuipers 2011) or the social and political uproar following the performance of Thomas Bernhard's Heldenplatz in Vienna in 1987 (Zangl 2013).

2 We draw this insight in analogy to Peter Szondi's approach to 'drama' as being "historically bound in its origins as well as in its content" (Szondi 1987: 5).

3 The name WIENWOCHE can be read both as an allusion to the prestigious Wiener Festwochen as well as to the campaign "Austria's youth gets to know its federal city" organized by the Federal Ministry of Education.

${ }^{4}$ The Call for the Anthropophagic Week on occasion of 20 years of maiz opens with a quote of Paulo Sergio Rouanet's "Manifesto antropofágico: 70 anos depois": "We do not eat to form our identity, but rather to de-form it and to newly re-form it again and again." (About the Archive of Errors! | maiz.)

${ }^{5}$ Return of Border Brujo, private video recording.

\section{References}

About the Archive of Errors! | maiz. Available online: http://www.maiz.at/en/subproject/aboutarchive-errors [Accessed 28 September 2014].

Bakhtin, M. (1981). The Dialogic Imagination. Four Essays by M. M. Bakhtin. Ed. by M. Holquist, transl. by C. Emerson \& M. Holquist. Austin \& London: University of Texas Press.

Bakhtin, M. (1984). Rabelais and His World. Transl. by Hélène Iswolsky. Bloomington: Indiana University Press. 
Bala, S. and Zangl, V. (2015). 'Humour's opponents: Artistic activism and the ludic aesthetic', in Weibel, P. (ed.), Global Activism: Art and Conflict in the $21^{\text {st }}$ Century. MIT Press, pp. 80-85.

BAVO (eds.) (2007). Cultural Activism Today. The Art of Over-Identification. Rotterdam: Episode Publishers.

Benjamin, W. (1999). The Arcades Project. Transl. by H. Eiland \& K. McLaughlin. Cambridge: Belknap Press.

Bergson, H. (1999). Laughter. An Essay on the Meaning of the Comic. Los Angeles, CA: Green Integer.

Billig, M. (2005). Laughter and Ridicule. Towards a Social Critique of Humour. London, Thousand Oaks, New Delhi: Sage.

Bishop, C. (2004). 'Antagonism and relational aesthetics', October 110, pp. 51-79.

Boenisch, P. M. (2012). 'Acts of spectating: The dramaturgy of the audience's experience in contemporary theatre', Critical Stages - Scenes critiques. IATC Webjournal 7. Available online: $\quad$ http://archive.criticalstages.org/criticalstages7/entry/Acts-of-Spectating-TheDramaturgy-of-the-Audiencersquos-Experience-in-ContemporaryTheatre\#sthash.szJpLENz.dpbs [Accessed 3 September 2015].

Derrida, J. (1996). Archive Fever: A Freudian Impression. Transl. by Eric Prenowitz. Chicago: University of Chicago Press.

Elahi, H. (2011). 'You want to track me? Here you go, F.B.I.', New York Times. Op-ed. 30 October 2011, p. SR6.

Elahi, H. (2014). 'Tracking Transience'. Available online: http://trackingtransience.net [Accessed 05 February 2014].

European Journal of Humour Research 1 (2), 2013 (= Special issue on Political Humour).

Gomez-Peña, G. (1989). Border Brujo. Filmed by Isaac Artenstein. 60 min.

Grindon, G. (2010). 'The notion of irony in cultural activism', in Özden Firat, B. \& Kuryel, A. (eds.), Cultural Activism: Practices, Dilemmas and Possibilities. Thamyris/Intersecting: Place, Sex and Race (Book 21). Amsterdam: Rodopi, pp. 21-34.

Hart, M. \& Bos, D. (eds.) (2008). Humor and Social Protest. Cambridge, New York: Cambridge University Press.

Holmes, B. (2009). Escape the Overcode. Activist Art in the Control Society. Eindhoven, Zagreb, Istanbul: Van Abbemuseum Public research \#2 and WHW.

Kerkhoven, M. van (2009). 'European dramaturgy in the 21st century', Performance Research: A Journal of the Performing Arts, 14:3, pp. 7-11.

Kuipers, G. (2011). 'The politics of humour in the public sphere. Cartoons, power and modernity in the first transnational humour scandal', European Journal of Cultural Studies 14 (1), pp. 63-80.

Morreall, J. (2009). Comic Relief: A Comprehensive Philosophy of Humor. Oxford: WileyBlackwell.

Müller, G. (2008). Possen des Performativen. Wien: Turia + Kant.

Pewny, K. \& Callens J. \& Coppens J. (eds.) (2014). Dramaturgies in the New Millennium: Relationality, Performativity and Potentiality. Forum Modernes Theater, 44. Tübingen: Narr Francke.

Sheftel, A. (2012). 'Monument to the international community, from the grateful citizens of Sarajevo: Dark humour as counter-memory in post-conflict Bosnia-Herzegovina', Memory Studies 5 (2), pp. 145-164. 
Sørensen, M.J. (2008). 'Humor as a serious strategy of nonviolent resistance to oppression', Peace \& Change 33 (2), pp. 167-190.

Szondi, P. (1987). Theory of the Modern Drama. Ed. and transl. by Michael Hays. Cambridge: Polity Press.

Trencsényi, K. \& Cochrane, B. (2014). New Dramaturgy. International Perspectives on Theory and Practice. London: Bloomsbury.

Zangl, V. (2013). 'Austria's post-89: Staging suppressed memory in Elfriede Jelinek's and Thomas Bernhard's Plays Burgtheater and Heldenplatz', in Mithander, C., Sundholm J. \& Velicu, A. (eds.). European Cultural Memory Post-89. Amsterdam: Rodopi, pp. 271-299. 